\title{
WACANA AMANDEMEN KELIMA \\ UNDANG-UNDANG DASAR 1945 SEBAGAI LANGKAH MEWUJUDKAN ARSITEKTUR KONSTITUSI DEMOKRATIK
}

\author{
Oleh: Mohammad Maiwan*
}

\begin{abstract}
The amendment of constitution is something commonly done and is part of the practice of national life. In Indonesian society there is some perspectives of the fifth constitution amendment. The first, is a group that wants the fourt constitution amendment retained. Secondly, a group that wants the amendment of the constitution. Third, is the group that want to go back to the original 1945 constitution. However, the amendment must be conducted in-depth, thorough, consistent, integrated, thus strengthening the Indonesian constitutional system. The main aspect that should be emphasized is to restore sovereignty to the people through the implementation of participatory democracy and good governance.
\end{abstract}

Key Words: Constitution, amendment, discourse.

\section{Pendahuluan}

Kewujudan konstitusi merupakan bagian penting dalam kehidupan negara. Selain memuat kandungan nilai-nilai fundamental serta rancangan dasar pengaturan negara, konstitusi juga memuat cita-cita, mimpi-mimpi, visi, sekaligus haluan jangka panjang yang akan diwujudkan suatu bangsa. Dengan kata lain, ianya memberikan gambaran akan corak dan arah perkembangan negara. Sebagai aturan dasar, konstitusi bukanlah merupakan benda mati yang tidak bisa diubah, melainkan bersifat dinamis sesuai dengan perkembangan jaman. Dalam konteks ini, suatu konstitusi secara ideal selayaknya bersifat antisipatif, dalam artian jauh berwawasan ke depan, menjangkau masa depan kehidupan bangsa, serta tidak terjebak dalam tataran pemecahan problem jangka pendek serta kepentingan-kepentingan politik dan ekonomi yang sempit dan sesaat.

Di kalangan masyarakat Indonesia, meskipun UUD 1945 telah diamandemen selama empat kali melalui satu tahapan politik yang menguras energi politik bangsa, dan dalam banyak hal menghasilkan sejumlah perubahan besar, namun sejauh ini dalam prakteknya menimbulkan implikasi yang kontraproduktif dengan pengembangan dan penguatan demokrasi, serta peningkatan kesejahteraan rakyat. Alih-alih penerapan konstitusi hasil amandemen keempat berjalan baik, realitas yang terjadi dalam kehidupan kenegaraan kita justru menunjukkan kualitas demokrasi kita yang 
$70 \quad \mid \begin{aligned} & \text { JURNAL ILMIAH MIMBAR DEMOKRASI } \\ & \text { VOLUME 12, NOMOR 2, APRIL } 2013\end{aligned}$

merosot, yang ditandai dengan munculnya beberapa masalah seperti: Kerancuan atau ketidakpastian dalam hubungan antara lembaga negara, dominasi ekonomi pasar bebas, maraknya politik transaksional dan politik berbiaya tinggi, lemahnya penegakan hukum, lunturnya budaya civic, serta marjinalisasi kehidupan rakyat bawah yang semakin kentara.

Karena itu, wajar jika dalam beberapa tahun belakangan muncul desakan kuat dari sebagian kalangan untuk melakukan amandemen kelima UUD 1945.

Terlepas dari berbagai kepentingan politik yang muncul di balik wacana amandemen tersebut, namun yang jelas konstitusi hasil amandemen belum dapat memenuhi harapan maksimal masyarakat. Nampak bahwa kritik-kritik dan perdebatan yang muncul mencerminkan bahwa UUD 1945 hasil amandemen mulai dari yang pertama sampai dengan keempat belum mampu memberikan rumusan yang memadai bagi adanya suatu konstitusi yang secara visioner menjawab tantangan di masa mendatang.

Meskipun belakangan, untuk sementara waktu, wacana dan perdebatan untuk mengamandemen UUD 1945 nyaris terhenti, mengingat konsentrasi masyarakat menghadapi pemilu 2014, namun tidak dapat dipungkiri pada akhirnya wacana itu akan berlanjut kembali dalam beberapa tahun ke depan. Untuk memahami lebih dalam bagaimana substansi wacana dan titik krusial perdebatan tersebut, serta bagaimana implikasnya terhadap praktekpraktek kehidupan negara, maka artikel ini berusaha menguraikannya.

\section{Beberapa Pandangan}

Di kalangan masyarakat Indonesia, berkembang beberapa perspektif menyangkut konstitusi pasca amandemen keempat. Pertama, adalah kelompok yang tetap menginginkan UUD hasil amandemen keempat tetap dipertahankan. Kelompok ini melihat bahwa konstitusi pasca amandemen sudah cukup sempurna, yang merupakan hasil kerja maksimal anak bangsa yang masih memadai untuk dijalankan. Proses amandemen yang berlangsung sampai dengan empat kali, dengan berbagai pergulatan kepentingan serta proses yang cukup panjang di dalamnya, menunjukkan bahwa konstitusi tersebut merupakan wujud kerja keras yang tidak bisa diabaikan.

Kelompok ini berargumen bahwa, terlepas dari segala kekurangan yang ada, dalam batas-batas tertentu, konstitusi pasca amandemen telah jauh mengalami penyempurnaan dan perbaikan dibanding sebelumnya. Munculnya beberapa aspek pemerintahan yang dianggap melenceng ataupun kontraproduktif selama ini, tidaklah serta merta dapat ditimpakan pada kesalahan konstitusi sebagai sumber 
utamanya, akan tetapi lebih pada pelakupelaku ataupun aktor penyelengggara negara itu sendiri. Karena itu, usaha penyempurnaan konstitusi, lebih baik dilakukan melalui berbagai jenis peraturan perundangan di bawahnya ataupun membenahi perilaku aparatur pemerintah.

Dalam pandangan kelompok ini, belum cukup waktu untuk melihat hasil amandemen yang baru sepuluh tahun lalu dilaksanakan. Justru yang diperlukan saat ini adalah melakukan dialog dengan masyarakat secara luas serta terus menerus mensosialisasikannya (Kompas, 11 Agustus 2012). Bagaimanapun juga, semua konstitusi pasti mengalami kekurangan, karena penyusunan konstitusi merupakan proses politik, sehingga tidaklah mengherankan jika yang dihasilkan bukanlah merupakan konstitusi yang terbaik, sebab di dalamnya ada berbagai macam pertarungan ide, gagasan, kepentingan serta kompromi-kompromi. Lagi pula perubahan konstitusi kelima secara teknis akan sangat berat mengingat adanya ketentuan dalam Pasal 37 UUD 1945 yang menyebutkan bahwa usulan perubahan harus disampaikan oleh sepertiga anggota MPR, sementara perubahan baru dapat dilakukan jika disetujui oleh 50\% ditambah satu anggota MPR.

Kedua, kelompok yang menginginkan adanya amandemen terhadap UUD 1945 hasil amandemen keempat. Kelompok ini berpendapat bahwa Undang-Undang Dasar hasil amandemen keempat mengandung beberapa kelemahan dan bertentangan dengan sistem ketatanegaraan yang kita anut, sehingga perlu penyempurnaan lebih jauh. Dalam pandangan kelompok ini, konstitusi bukanlah harga mati yang tidak bisa diubah, melainkan merupakan kebijakan hukum yang terbuka yang bisa diubah sesuai dengan kebutuhan atau perkembangan zaman. Kandungan pasal dan ketentuan hukum di dalamnya merupakan pilihan dan kesepakatan para pembuatnya. Sebab bagaimanapun setiap generasi memiliki problematikanya sendiri dan karenanya berhak memiliki konstitusinya sendiri sesuai dengan apa yang dibutuhkan. Pendukung kelompok ini adalah terutama dipelopori anggota Dewan Perwakilan Daerah (DPD).

Ada beberapa aspek penting yang dikemukakan kelompok ini, yakni: (1) Kandungan yang terdapat dalam konstitusi pasca amandemen meletakkan kewenangan yang begitu besar pada Dewan Perwakilan Rakyat (parlemen), sehingga pada derajad tertentu mengurangi efektifitas pemerintahan yang pada intinya bersifat presidensiil. Dalam prakteknya, corak pemerintahan kita lebih mirip dengan sistem pemerintahan parlementer; Penataan kelembagaan dan hubungan antar 
72 JURNAL ILMIAH MIMBAR DEMOKRASI

lembaga, khususnya penguatan fungsi lembaga Dewan Perwakilan Daerah yang seharusnya memiliki kewenangan sejajar dengan Dewan Perwakilan Rakyat. Sistem bikameral (dua kamar) dalam legislatif yang selama ini dipraktekkan lebih banyak memberikan kewenangan kepada DPR, sementara DPD nyaris hanya sebagai lembaga simbolik saja; (3) Pengaturan menyangkut otonomi daerah, yang memberikan kerangka acuan bagi terlaksananya kekuasaan pemerintahan yang efektif yang berdampak luas pada kesejahteraan rakyat. Sejauh ini, penerapan otonomi daerah kebanyakan justru menghasilkan inefisiensi pemerintahan, politik biaya tinggi, munculnya politik dinasti, konflik antarwarga, merebaknya korupsi di daerah, dan lain-lain.

Ketiga, adalah kelompok yang ingin kembali kepada UUD 1945 yang asli. Penyokong kelompok ini sebagian adalah para purnawirawan Tentara Nasional Indonesia, seperti Jenderal (Purn.) Try Sutrisno, Letjen (Purn.) Agum Gumelar, Prof. Dimyati Hartono, dan lain-lain. Kelompok ini berpandangan bahwa selama empat kali proses amandemen UUD 1945 lebih banyak terjadi perubahan yang bersifat drastik karena merubah platform kenegaraan kita secara total dan mendasar, serampangan, berorientasi politik jangka pendek, sehingga menghancurkan spirit konstitusi sepertimana disusun para pendahulu kita. Fakta yang terjadi sesungguhnya bukanlah menyempurnakan, melainkan mengganti UUD berkenaan karena isinya sudah jauh menyimpang. Nampak bahwa dengan serentetan amandemen itu, menjadikan konstitusi kita amat liberal, yang berimbas pada penerapan tatanan politik, ekonomi, sosial dan budaya liberal pula. Dalam beberapa aspek, praktek kehidupan kita justru lebih liberal dibandingkan dengan negara kampium demokrasi liberal sekalipun, yakni Amerika Serikat sendiri.

Bahkan mantan Ketua Umum Pengurus Besar Nahdlatul Ulama, K.H. Hasyim Muzadi dengan nada keras menyatakan bahwa empat kali amandemen UUD 1945 selama ini telah menghancurkan Pancasila (Kompas, 10 September 2012). Menurut beliau, meskipun Pembukaan UUD 1945 tidak diubah, akan tetapi amandemen terhadap batang tubuh yang menyentuh sendi-sendi operasional justru menghancurkan Pancasila. Akibatnya, kehidupan ekonomi, politik, sosial dan budaya "bocor" dan melenceng dari arah yang sebenarnya.

Dalam pandangan kelompok ini, kembali ke UUD 1945 asli bukanlah sesuatu yang haram, melainkan justru merupakan jalan keluar untuk menjauhi praktek kenegaraan yang bisa membangkrutkan masa depan kita. Tindakan tersebut bukanlah merupakan 
langkah mundur, melainkan usaha kembali kepada roh kebangsaan yang sejati. Fakta yang terjadi sesungguhnya selama ini UUD 1945 yang asli belum pernah dilaksanakan secara konsekwen, mulai dari zaman Presiden Soekarno, Presiden Soeharto, sampai kemudian masa reformasi tahun 1999 (A.M. Fatwa 2009: 33-34). Ada persepsi luas yang berkembang bahwa UUD 1945 ketinggalan zaman dan tidak cukup memadai untuk memecahkan persoalan-persoalan bangsa dewasa ini. Meskipun demikian, pandangan golongan ini memberikan kemungkinan bagi adanya ruang perbaikan pada konstitusi 1945, dalam artian restorasi, tetapi bukan perubahan yang drastis sepertimana yang muncul dalam versi konstitusi pasca amandemen sekarang.

\section{Substansi dan Aspek-Aspek Wacana}

Menurut sebagian kalangan perubahan keempat UUD 1945 sejak tahun 1999-2002 masih menyisakan banyak persoalan penting yang belum tuntas, sehingga berimplikasi pada penyelenggaraan kekuasaan negara yang tidak konsisten. Persoalan-persoalan yang muncul tersebut menyangkut antara lain: Pada tingkat legislatif, hubungan Dewan Perwakilan Rakyat (DPR) dengan Dewan Perwakilan Daerah (DPD) terwujud dengan baik, seimbang dan tepat. Di samping itu juga hubungan antara lembaga-lembaga negara yang ada, seperti Mahkamah Konstitusi, Mahkamah Agung, Komisi Yudisial, Komisi Pemberantasan Korupsi perlu diperkuat, sehingga tidak saling mencampuri atau mengganggu satu sama lain yang menimbulkan konflik kelembagaan.

Dewasa ini, pelaksanaan sistem perwakilan dua kamar atau bikameral terlihat pincang, di mana kewenangan DPR terlalu besar, sementara DPD amat terbatas. Akibatnya institusi DPR agak sewenang-wewenang dan cenderung koruptif karena tidak ada kekuatan penyeimbang. Konstitusi memang mengatur lembaga perwakilan yang disebut Majelis Permusyawaratan Rakyat (MPR) terdiri dari dua kamar, yakni DPR dan DPD. Namun kewenangan yang dimiliki DPR lebih besar dibandingkan kewenangan DPR yang justru merupakan representasi masyarakat daerah.

Pada satu sisi DPR memiliki kewenangan dalam: Menetapkan anggaran pemerintah dan mengesahkan undangundang (UU); mengajukan usulan hak menyatakan pendapat kepada MPR; memiliki hak untuk melakukan uji kelayakan dan kepatutan sejumlah pejabat serta komisioner negara. Sementara pada lain pihak DPD tidak memiliki hak dalam menetapkan anggaran dan hak menyatakan pendapat. DPD hanya memiliki hak mengusulkan rancangan undang-undang 
yang menyangkut pelaksanaan pemerintahan dan pembangunan daerah, serta belakangan melalui uji materi di Mahkamah Konstitusi, memperoleh hak dalam pembahasan rancangan undangundang tetapi tidak memiliki hak untuk mengesahkan menjadi Undang-Undang. Dengan kewenangan yang seimbang, DPR dan DPD diharapkan bisa saling mengawasi sehingga kesewenangwenangan dan praktek koruptif DPR bisa diminimalisasi.

Menurut pengamat politik $\mathrm{M}$. Qodari, permasalahan yang dihadapi DPD bukanlah Pasal 22C dan 22D UUD 1945 yang mengatur tentang DPD. Pasal yang seharusnya diamandemen adalah Pasal 20 UUD 1945 yang mengatur kewenangan DPR untuk menyusun Undang-Undang. Pasal itu menyebutkan, setiap RUU dibahas oleh DPR dan Presiden untuk mendapat persetujuan bersama (Kompas 5 Oktober 2013).

Sementara pada tingkat eksekutif, perlu penguatan sistem presidensial, di mana mesti ada keseimbangan peran antara eksekutif dengan legislatif, di mana sejumlah kewenangan yang selama ini berada di tangan presiden, yang dikurangi dalam empat kali amandemen perlu ditinjau lagi. Dalam naskah konstitusi hasil amandemen itu, meskipun wewenang presiden cukup luas tetapi tetap dalam bayang-bayang parlemen karena hampir di dalam setiap kebijakannya memerlukan persetujuan DPR (UUD 1945 Pasal 7-16).

Mulai dari masalah pemberhentian Presiden dan Wakil Presiden, pengangkatan para pejabat negara, sampai dengan pembentukan Dewan Pertimbangan Presiden. Salah satu kewenangan utama parlemen yang jelas-jelas ditunjukkan untuk mengimbangi kewenangan presiden adalah dalam Pasal 19-22B UUD 1945, di mana fungsi utama DPR bukan hanya pengawasan dan penganggaran saja, tetapi juga pengajuan rancangan undang-undang atau legislasi. Secara politis, teramat kuatnya kedudukan parlemen tersebut, sepertimana dikemukakan Jimly Asshiddiqie, menjadikan tatanan kenegaraan kita lebih cenderung legislative heavy (Asshiddiqie 2010b: 117).

Ketimpangan wewenang itu, pada tahap tertentu, dapat berakibat mengganggu, bahkan memunculkan konflik antar lembaga eksekutif dan legislatif sebagaimana sering kita saksikan. Padahal, idealnya hubungan antara legislatif-eksekutif bersifat seimbang sesuai dengan fungsinya masing-masing. Konflik itu wujud, karena arogansi wewenang dan adanya kepentingan politik sesaat. Semangat kontrol DPR yang berlebihan atau tidak proporsional untuk tujuan-tujuan politik, seringkali mengkandaskan berbagai kebijakan eksekutif, sehingga pihak eksekutif seringkali "tersandera" oleh legislatif. 
Berkali-kali ketegangan antara pihak legislatif dan eksekutif muncul ke permukaan, dan menimbulkan krisis politik.

Dominannya peran DPR dalam konstitusi hasil amandemen tersebut ini tidak bisa dilepaskan dari suasana kebatinan saat proses perubahan itu dilakukan, yakni adanya keinginan yang kuat untuk memperkuat lembaga legislatif. Keinginan muncul sebagai antitesis dari pemerintahan Orde Baru yang baru saja berakhir pada saat itu, yang sebelumnya menempatkan presiden dalam posisi yang amat kuat. Jika kita ingin memperkuat sistem presidensiil murni serta melenyapkan berbagai kerumitan selama ini, maka seyogyanya prinsip-prinsip pemisahan kekuasaan (separation of powers) antara eksekutif, legislatif dan yudikatif itu perlu dijalankan. Hal ini terutama menyangkut sistem kepartaian dan legislasi.

Penataan sistem kepartaian perlu dilakukan, dalam arti penyederhanaan jumlah partai politik yang ada. Jumlah dan kedudukan partai-partai sepatutnya mencerminkan aliran-aliran politik utama yang hidup dalam masyarakat, sehingga tidak semua kelompok secara bebas mendirikan partai politik sesuai dengan selera. Pada sistem kepartaian yang bersifat multipartai yang kita anut sesungguhnya bertentangan dengan konsep pemerintahan presidensiil murni. Sistem multipartai sejajar dengan sistem pemerintahan parlementer. Dalam prakteknya pemerintahan disusun mengikuti model koalisi tetapi dalam parlemen partai-partai anggota koalisi pemerintah seringkali justru bertengkar satu sama lain. Koalisi "setengah hati" inilah yang menyebabkan pemerintahan tidak efektif. Penguatan sistem presidensial diharapkan akan membawa dampak ikutan pada kinerja legislasi, yakni fungsi legislasi DPR. Selama ini, rendahnya tingkat produktifitas DPR disebabkan karena tidak tegasnya aturan dalam konstitusi (Hasan 2010).

Dalam sistem presidensiil pembuatan undang-undang atau legislasi cukup dilakukan oleh legislatif, sementara eksekutif hanya menjalankannya. Kendati demikian, presiden tidak berarti pasif sama sekali, tetapi diberi peluang untuk menyetujui atau menolak undang-undang tersebut dengan mekanisme hak veto. Fakta yang terdapat dalam konstitusi amandemen memperlihatkan penggabungan kekuasaan antara kedua lembaga ini. Hal tersebut misalnya, tampak pada Pasal 20 ayat (2) yang berbunyi, "Setiap rancangan undang-undang dibahas oleh DPR dan presiden untuk mendapatkan persetujuan bersama”. Karena itu setiap pembuatan undang-undang di DPR pasti melibatkan presiden, yang dalam hal ini diwakili menteri-menteri terkait. Keadaan ini membawa implikasi pada lemahnya 
produktifitas legislatif karena prosesnya cukup berbelit, serta menimbulkan pemborosan uang negara. Pada segi lain ini juga berakibat pada munculnya praktek kolusi dan korupsi di antara kedua belah pihak. Dengan penguatan sistem presidensial maka berbagai kerancuan dan ketidakjelasan dalam sistem pemerintahan yang ada sekarang bisa diatasi.

Selanjutnya, pada bidang politik, sebagai bagian dari penguatan sistem demokrasi maka oligarki partai-partai dalam politik perlu dikurangi dengan cara mengakomodasi rekruitmen kepemimpinan nasional dari jalur independen. Dengan adanya calon presiden independen maka proses politik akan berlangsung kompetitif dan rakyat memperoleh pilihan yang terbaik sesuai dengan kehendaknya. Menurut Wakil Ketua MPR Hajriyanto Y. Tohari, pemilihan presiden semestinya tidak menghalangi warga negara untuk mencalonkan diri. Di samping itu, kehadiran calon perseorangan juga akan menyegarkan pola pencalonan dan mengurangi praktek kartel politik (Kompas 2 April 2011). Keberadaan capres independen dirasa perlu mengingat kekecewaan rakyat terhadap partai politik selama ini. Hal ini sekaligus merupakan peringatan bagi partai-partai politik agar lebih serius melakukan kaderisasi dan perekrutan calon presiden dan tidak melihatnya sebatas transaksi politik belaka.
Sejauh yang kita lihat sumber kepemimpinan nasional yang ada, dimonopoli oleh elite-elite tertentu yang ada dalam partai-partai politik, di mana mereka bersifat oligarkis karena distribusi kader ke jabatan-jabatan publik hanya ditentukan oleh segelintir elite partai. Dalam prakteknya, tidak nampak adanya mekanisme demokratis. Kenyataan tersebut dibarengi dengan tradisi transaksional dalam proses politik yang berbiaya tinggi, yang hanya mampu diikuti oleh mereka yang memiliki sumberdaya material yang memadai. Dengan kata lain, pemilik uang akan mengendalikan kebijakan. Dominasi kekuatan material inilah yang mampu mendistorsi sistem politik dan membelokkan demokrasi ke arah yang lain.

Menurut Jeffrey Winters, di antara semua sumber kekuasaan politik di Indonesia, kekuasaan secara material merupakan yang paling terkonsentrasi dan memiliki sedikit kendala, sehingga membuka peluang besar adanya praktek oligarki. Semakin senjang distrubusi kekayaan akan memberikan pengaruh besar bagi oligarki dalam mencapai motif dan tujuan politik mereka (Winters 2011: 206-286). Karena itu, tidaklah mengejutkan jika kemudian banyak elite politik yang membarter kewenangan yang mereka miliki dengan suntikan dana dari kekuatan kapital tertentu yang mempunyai 
kepentingan ekonomi, ataupun juga para pemilik kapital -terutama kekuatan lama-sengaja secara langsung terjun ke dalam dunia politik dan mengkolonisasi demokrasi.

Aspek lain yang perlu menjadi fokus penting dalam amandemen konstitusi adalah bidang otonomi daerah agar hubungan antara pemerintah pusat dan daerah semakin erat, dalam arti hubungan pusat dan daerah diperkuat. Karena selama kurang lebih tiga belas tahun pelaksanaan desentralisasi di Indonesia belum membawa manfaat besar bagi masyarakat. Berbagai persoalan muncul di daerah, mulai dari konflik politik, menguatnya politik identitas, kekerasan antar warga, sengketa wilayah, pengurasan sumberdaya alam secara tak terkendali, korupsi yang menyebar, buruknya infrastruktur, munculnya politik dinasti, hancurnya lingkungan, ledakan jumlah penduduk, buruknya kualitas dan integritas birokrasi, serta rendahnya mutu pelayanan publik, yang berujung pada memburuknya kualitas pembangunan secara keseluruhan. Dalam bahasa yang lain, desentralisasi justru mencetuskan anomali dalam pembangunan. Alih-alih otonomi diimpikan sebagai sarana menyatukan rakyat, namun justru berpotensi melemahkan integrasi nasional, di tengah gencarnya elite kepemimpinan nasional menyuarakan konsep Negara Kesatuan
Republik Indonesia (NKRI) yang terlalu dimistifikasi.

Karena itu, perlu penataan semula desain otonomi daerah dalam kerangka yang lebih mapan dan mantap, apakah tetap seperti sekarang dengan titik berat pada daerah kabupaten/kota atau dikembalikan ke propinsi, mengingat skala pertumbuhan ekonomi, pertambahan jumlah penduduk, atau urgensi koordinasi? Secara prinsip proses desentralisasi perlu dibarengi dengan inovasi sistemik secara radikal untuk melenyapkan hambatanhambatan yang ada. Sejauh ini, ada beberapa masalah yang dihadapi, yakni: Pertama, porsi anggaran pembangunan daerah yang amat kecil, di mana sebagian besar dana pembangunan tersedot untuk belanja rutin pegawai, sementara alokasi untuk realisasi pembangunan tetap kecil hanya sekitar 30-40 persen saja.

Kedua, adanya persaingan antar daerah dalam hal pembangunan wilayah berdasarkan egoisme kewilayahan dan juga sektoral. Desentralisasi seharusnya memompa semangat antar daerah untuk saling bersinergi. Ketiga, terpotongnya partisipasi publik dari bawah karena birokrasi dan partai politik. Padahal desentralisasi dan pelimpahan kewenangan kepada pemerintah daerah akan membawa manfaat kepada masyarakat jika mereka dilbatkan dalam partisipasi, khususnya dalam pembuatan kebijakan, baik pada 
$78 \quad \mid \begin{aligned} & \text { JURNAL ILMIAH MIMBAR DEMOKRASI } \\ & \text { VOLUME 12, NOMOR 2, APRIL } 2013\end{aligned}$

pembuatan peraturan daerah maupun penentuan kebijakan layanan publik. Tanpa adanya partisipasi masyarakat desentralisasi hanya menguntungkan segelintir elite di daerah dan memunculkan oligarki-oligarki daerah yang berujung korupsi dab pembajakan demokrasi secara sistematis.

Sementara di bidang ekonomi konstitusi amandemen telah ikut mendorong lahirnya kebijakan ekonomi yang bersifat liberal. Pada perubahan keempat UUD 1945 ditambahkan ayat (4) dan (5) Pasal 33 UUD 1945 yang berbunyi:

(4) Perekonomian nasional diselenggarakan berdasar atas demokrasi ekonomi dengan prinsip kebersamaan, efisiensi berkeadilan, berkelanjutan, berwawasan lingkungan, kemandirian, serta menjaga keseimbangan kemajuan dan kesatuan ekonomi nasional.

(5) Ketentuan lebih lanjut mengenai pelaksanaan pasal ini diatur dalam undang-undang.

Meskipun pasal 33 UUD 1945 yang asli tidak diubah namun dengan penambahan tersebut secara normatif telah merubah pasal 33. Dikatakan demikian, mengingat dalam rumusan normatif dalam Penjelasan UUD 1945 tentang "bangun perusahaan (yang berupa) koperasi" tidak dimasukkan dalam pasal-pasal. Padahal sesuai dengan kesepakatan MPR tahun 1999 seharusnya muatan normatif dalam Penjelasan UUD 1945 itu dimasukkan ke dalam pasal-pasal (Aidul Fitriciada 2011:163). Ini jelas merupakan penolakan terhadap Pasal 33, meskipun mencantumkannya tetapi hakikatnya menolak rumusan normatif yang ada dalam Penjelasan.

Di samping itu, masuknya kata-kata "efisiensi berkeadilan" menunjukkan adanya keberpihakan pada kepada kekuatan pasar. Inkonsistensi itu menunjukkan adanya pertarungan ideologis di kalangan penyusun konstitusi. Apalagi terdengar bahwa Pasal 33 sebelumnya mau dirubah karena dianggap tidak sesuai dengan perkembangan zaman. Namun tindakan tersebut tidak jadi dilakukan karena memperoleh penolakan keras dari masyarakat. Sebagai akibat dari perubahan Pasal 33 UUD 1945 itu menyebabkan ekonomi Indonesia cenderung berkembang ke arah sistem ekonomi neoliberal. Dalam sistem ini negara lebih mementingkan hak-hak milik individu, aturan-aturan hukum dan pranatapranata pasar bebas serta perdagangan bebas (Aidul Fitriciada 2011:168).

Liberalisasi pasal-pasal dalam konstitusi amandemen sekali lagi mencerminkan adanya perbedaan kepentingan di antara berbagai kelompok yang terlibat, yang mana tidak menutup 
kemungkinan ditunggangi kepentingan asing. Hal ini seperti ditegaskan mantan Wakil Kepala Staf Angkatan Darat Letnan Jenderal (Purn.) Kiki Syahnakrie yang menyatakan bahwa LSM asing, National Democratic Institution (NDI) di bawah Partai Demokrat Amerika Serikat telah menggelontorkan 45 juta dolar US untuk mengawal amandemen konstitusi Indonesia sejak 1999 hingga 2002. Karena itu, menurut beliau, tidaklah mengherankan jika terdapat berbagai produk hukum turunan konstitusi yang begitu akomodatif terhadap kepentingana asing. Bahkan disinyalir 82,5 persen isi amandemen UUD 1945 mengandung muatan liberal (Jawa Pos 9 Februari 2012).

Salah satu kelemahan lain UUD amandemen keempat adalah tidak terdapatnya acuan atau grand design pembangunan dalam jangka panjang semacam GBHN (Garis-Garis Besar Haluan Negara) sebelum ini. Hilangnya GBHN dalam konstitusi dirasakan sangat fatal karena menyangkut pedoman bangsa dalam mencapai cita-cita nasional. Ianya tidak bisa digantikan dengan agenda rancangan yang dilakukan setiap presiden dalam setiap masa jabatannya. Hal itu seperti pernah dikemukakan mantan Wakil Presiden Try Sutrisno, yang menyatakan bahwa, GBHN tidak bisa digantikan oleh Rencana Pembangunan Jangka Menengah (RPJM) dan Rencana Pembangunan
Jangka Panjang (RPJP), sebagaimana berlaku saat ini, mengingat ianya hanya mengakomodir visi dan pemerintah (eksekutif) saja. Sedangkan GBHN yang disusun oleh MPR mengakomodir seluruh kepentingan rakyat.

Secara teoritik, hilangnya GBHN sebagai haluan pembangunan adalah akibat sistem presidensial murni pada amandemen UUD 1945 yang menunjukkan berlakunya model mobilisasi sosial yang berwatak reaktif. Dengan sistem ini, memang pemerintah akan lebih fleksibel sesuai dengan tuntutan kebutuhan pasar, akan tetapi cenderung dikendalikan kelompokkelompok stratitikasi sosial tinggi yang kemungkinan memiliki kepentingan berbeda dengan rakyat. Sebab bagaimanapun juga melalui segenap sumberdaya yang dimiliki kelompokkelompok sosial tinggi ini dapat mengendalikan suara rakyat (Azhari 2011:161-162). Secara praktis, setiap presiden bebas menjalankan agenda pembangunannya sendiri dari satu period ke periode yang lain, yang boleh jadi hanya menyesuaikan diri dengan tuntutantuntutan pasar. Realitas itu berbeda jika pemerintahan presidensial yang dibimbing oleh GBHN, yang memungkinan pemerintah lebih kedap terhadap tuntutan rakyat dan rigid dalam mengarahkan pembangunan. 


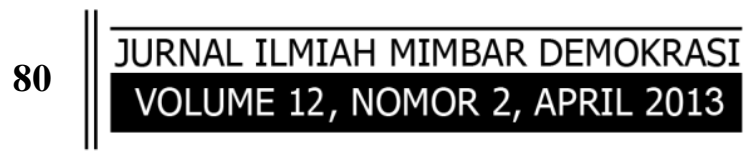

\section{Prospek dan Kerangka}

Dengan melihat kecenderungan politik yang terjadi serta dinamika kehidupan nasional di masa mendatang, maka amandemen nampaknya tidak akan bisa dihindari. Amandemen konstitusi merupakan bagian penting dari kehidupan kenegaraan yang seharusnya terbuka untuk diwacanakan. Mengingat empat kali amandemen UUD 1945 yang sebelumnya tidak membawa rakyat Indonesia pada kondisi yang lebih baik daripada sebelum reformasi bergulir maka amandemen perlu dipertimbangkan baik-baik. Namun demikian, hendaknya gagasan amandemen tersebut hendaknya tetap memperhatikan amanat dan semangat UUD yang asli.

Seperti dikemukakan oleh Valina Singka Subekti (2008) bahwa, salah satu sebab munculnya berbagai permasalahan dalam konstitusi adalah karena proses penyusunan konstitusi merupakan bagian dari pergulatan kepentingan yang berbagai kelompok dan faksi. Proses politik selama perubahan konstitusi di MPR selalu diwarnai dengan kompetisi, bargaining, serta kompromi. Karena itu, tidaklah mengherankan jika ada kelemahan di sana sini. Perbaikan kualitas sistem kenegaraan perlu pembenahan agar tidak menimbulkan kerancuan sistemik yang selalu berulang. Diharapkan dengan amandemen akan memperkuat sistem ketatanegaraan Indonesia. Terlalu banyaknya gonjang- ganjing pemerintahan selama ini, seperti keruhnya hubungan eksekutif-legislatif beberapa waktu yang lalu, menyebabkan pemerintahan tidak efektif karena tersandera oleh berbagai kepentingan yang saling bertentangan

Dalam kaitan ini, amandemen jangan dilakukan oleh kaum politisi ataupun ideolog tetapi oleh para pakar independen yang memiliki kemampuan dan kapasitas yang mumpuni di bidangnya masing-masing. Jika dilakukan oleh politisi maka akan terlalu banyak kepentingan yang masuk, yang dikhawatirkan kandungan konstitusi akan bias kepada kepentingan tertentu ataupun mudah disalahtafsirkan sesuai dengan selera kelompok masing-masing. Tekanan utama yang harus diberikan adalah mengembalikan kedaulatan kepada rakyat melalui pelaksanaan demokrasi partisipatif dan tata kelola pemerintahan yang baik (good governance).

Hal ini berwujud pada pelibatan masyarakat dalam proses pengambilan keputusan, pemberdayaan ekonomi, pendidikan politik, penegakan hukum, peningkatan pendidikan merupakan kebijakan mutlak yang perlu terus ditingkatkan sehingga dapat mengurangi dampak negatif praktek-praktek oligarki seperti yang terjadi selama ini. Pada tahap ini, sikap yang paling penting adalah bagaimana pihak-pihak yang terlibat, 
khususnya elite poltik memahami bahwa kepentingan bangsa dan negara berada di atas kepentingan pribadi dan golongan. Jika ini tidak diresapi maka jiwa konstitusi akan kering dan jauh dari semangat pembaruan.

Di samping itu, apa yang perlu dilakukan adalah penegasan kembali spirit of power dalam kewenangan chek and balance oleh lembaga negara. Dalam konstruksi UUD hasil amandemen yang kita saksikan semua hal tersebut belum bisa dilakukan secara optimal karena konstitusi yang ada membatasi. Semua proses politik yang ada sebagian besar masih harus melalui partai politik. Dengan demikian seolah-olah UUD 1945 dimonopoli oleh partai politik. Terlalu banyak diakomodasinya kepentingan DPR mengisyaratkan bahwa peranan partai politik menduduki posisi yang amat strategis. Padahal partai-partai politik yang ada secara umum belumlah menunjukkan performa dan kepedulian yang tinggi sebagai institusi yang memperjuangkan aspirasi rakyat. Tidak sedikit ditemukan bahwa muatan konstitusi hasil amandemen keempat bersifat parsial, tidak sinkron dan konsisten satu sama lain.

Dalam konteks ini perlu diperhatikan bahwa hendaknya amandemen konstitusi mendasarkan diri pada prinsip-prinsip: Pertama, longevity, agar UUD itu dapat bertahan selama mungkin untuk puluhan tahun ke depan untuk kepentingn bangsa, sehingga tidak muda berubah-ubah; Kedua, rigidity, dalam arti agar ia cukup tegar atas berbagai perubahan yang terjadi; serta ketiga, muatan moral (moral content), yang mengaharapkan agar yang diubah bukan hanya sekedar struktur dasar pemerintahan saja tetapi juga harus memperhatikan hak asasi manusia. Pada akhirnya, kita perlu mengembangkan konsep pemikiran konstitusi demokratik sehingga melahirkan konstitusi yang dinamis.

\section{Kesimpulan}

Perubahan atau amandemen bukanlah merupakan sesuatu yang tabu untuk dilakukan, karena pada dasarnya setiap konstitusi perlu perbaikan sesuai dengan tuntutan zaman. Sebagai suatu konstitusi, UUD 1945 bukanlah suatu immortal constitution karena tidak tertutup kemungkinan bagi upaya perubahan. Akan tetapi, langkah tersebut perlu kajian serius dan mendalam. Mengingat konstitusi sebagai sumber inspirasi, wawasan dan cita-cita bangsa, maka setiap perubahan yang bakal dilakukan haruslah memberikan makna memperbaiki kepada keadaan yang lebih baik. Dalam kaitan ini, seyogyanya perubahan yang dilakukan tidak boleh melangkah mundur dari kemajuan demokrasi yang kita tempuh sekarang ini. 
Perlu disadari bahwa

ketidaksempurnaan yang terkandung dalam setiap konstitusi membuktikan pandangan bahwa konstitusi itu sendiri selalu tumbuh dan berkembang sesuai dengan perkembangan masyarakat. Konstitusi, termasuk dalam hal ini UUD 1945, selalu mungkin dapat berubah karena tidak ada yang dapat menyatakan bahwa konstitusi hari ini adalah yang terbaik bagi generasi mendatang. Dalam konteks ini, wacana perubahan UUD 1945 mendapatkan relevansinya dan perlu dipandang secara bijak sebagai bagian dari kegelisahan sebagian kalangan akan arah perjalanan bangsa Indonesia di masa mendatang.

Bagi kita semua, baik secara filosofis, yuridis, maupun praksis, UUD 1945 bukan saja merupakan konstitusi politik, tetapi juga konstitusi ekonomi, sosial budaya, yang menjadi rujukan dalam penyelenggaraan kehidupan bangsa dan negara. Di bidang politik, konstitusi tersebut haruslah menjadi acuan dalam penentuan berbagai kebijakan politik dan pemerintahan, sekaligus sumber inspirasi dan motivasi bagi setiap tindakan politik warganegara. Di bidang ekonomi, konstitusi 1945 seyogyanya menjadi sumber pedoman dalam menentukan haluan ekonomi negara, dengan titik capaiannya pada terwujudnya kedaulatan ekonomi yang berujung pada kesejahteraan rakyat. Sementara di bidang sosial budaya, konstitusi tersebut seyogyanya menjadi panduan untuk melahirkan insan Indonesia yang modern dan berkepribadian Indonesia.

\section{DAFTAR PUSTAKA}

Aidul Fitriciada Azhari, UUD 1945 Sebagai Revolutiegrondwet: Tafsir Postkolonial Atas GagasanGagasan Revolusioner dalam Wacana Konstitusi Indonesia, Yogyakarta: Jalasutra, 2011.

A.M. Fatwa, Potret Konstitusi Pasca Amandemen UUD 1945, Jakarta: Kompas, 2009.

"Amandemen UUD 1945 Hancurkan Pancasila", Kompas 10 September 2012.

Asshiddiqie, Jimly, Konstitusi dan Konstitusionalisme Indonesia, Jakarta: Sinar Grafika, 2010a.

Konsolidasi Lembaga Negara Pasca Reformasi, Jakarta: Sinar Grafika, 2010b.

\section{Green Constitution:}

Nuansa Hijau Undang-Undang Dasar Negara Republik Indonesia Tahun 1945, Jakarta: PT RajaGrafindo Persada, 2010c.

"Bermuatan Liberal, Amandemen UUD'45 Diintervensi AS", Jawa Pos, 9 Februari 2012.

"Calon Perseorangan Peringatan bagi Parpol”, Kompas 2 April 2011. 
Iding R. Hasan, "Menakar Urgensi Amandemen Kelima", Pikiran Rakyat 26 Agustus 2010.

"Jangan Sering Ubah UUD 1945", Kompas, 19 Agustus 2011.

"Konstitusi Bisa Diubah", Kompas, 11 Agustus 2012.

Ni'matul Huda, Lembaga Negara dalam Masa Transisi Demokrasi, Yogyakarta: UII Press, 2007.

"Penguatan Hanya Lewat Amandemen UUD”, Kompas, 5 Oktober 2013.

Saldi Isra, Pergeseran Fungsi Legislasi: Menguatnya Model Legislasi Parlementer dalam Sistem Presidensial Indonesia, Jakarta: PT RajaGrafindo Persada, 2010.
Strong, C.F., Konstitusi-Konstitusi Politik Modern: Studi Perbandingan tentang Sejarah dan Bentuk, Terj. Derta Sri Widowatie, Bandung: Nusa Media, tanpa tahun.

Undang-Undang Dasar Negara Republik Indonesia Tahun 1945, Jakarta: Sekretariat Negara Republik Indonesia, 2010.

Valina Singka Subekti, Menyusun Konstitusi Transisi: Pergulatan Kepentingan dan Pemikiran dalam Proses Perubahan UUD 1945, Jakarta: PT RajaGrafindo Persada, 2008.

Winters, Jeffrey A., Oligarki, Terj. Zia Anshor, Jakarta: PT Gramedia Pustaka Utama, 2011. 